\title{
Extra-gastrointestinal stromal tumor of the liver diagnosed by ultrasound-guided fine needle aspiration cytology: a case report and review of the literature
}

Zhou-Yu Li, Qi-Lian Liang, Guo-Qiang Chen, Yuan Zhou, Qiu-Long Liu

Department of Oncology, Affiliated Hospital of Guangdong Medical College, Zhanjiang, China

Submitted: 14 October 2011

Accepted: 21 November 2011

Arch Med Sci 2012; 8, 2: 392-397

DOI: 10.5114 /aoms.2012.28572

Copyright $\odot 2012$ Termedia \& Banach

Extra-gastrointestinal stromal tumor (EGIST) is a special type of gastrointestinal stromal tumor, which has similar biological characteristics to its counterpart, and occurs outside the gastrointestinal tract. It was identified first by Miettinen et al. [1], and named by Reith et al. [2]. The incidence of EGIST is extremely low, and so far there is no detailed epidemiological figure. To the best of our knowledge, EGIST has been commonly reported in the mesentery, omentum or retroperitoneum [1-4], and sporadically in the pleura [5], pancreas [6-12], liver [13-17], gallbladder [18], adrenal gland [19], bladder [20-22], prostate [23] and vagina [24, 25]. Most existing studies of EGIST are case reports, lacking enough information to clarify the disease; thus it is very difficult to establish helpful guidelines for clinicians. It is very common that EGIST is misdiagnosed for other tumors. Herein, we report an extra-gastrointestinal stromal tumor of the liver, which was diagnosed by ultrasound-guided fine needle aspiration cytology (US-FNAC), and review the literature, so as to help understand EGIST better.

A 53-year-old Chinese man was admitted to the Affiliated Hospital of Guangdong Medical College in July 2011 with the chief complaint of abdominal discomfort in the right upper quadrant for 1 month. The patient denied abdominal pain, diarrhea, nausea, vomiting, hematemesis, hematochezia, fevers or chills. There was no loss of appetite or weight. He had an ultrasound scan three days previously in a local hospital, revealing a giant mass in the liver. He had had sub-total gastrectomy because of gastric ulcer in 2005.

Physical examination showed a well-developed man with abdominal distention; yellow pigmented lesions, hepatic palm and spider angioma were not seen; palpation indicated a large mass extending subcostally approximately $18 \mathrm{~cm}$, moderately tender and non-pulsatile; percussion tenderness over hepatic region and shifting dullness were negative.

Contrast-enhanced computerized tomography of the upper abdomen was performed. It showed a giant irregular low-density mass almost occupying the full right lobe of the liver; it was encircled by rich blood vessels, and the maximum dimensions were about $17 \mathrm{~cm} \times 20 \mathrm{~cm}$; the pancreas and right kidney were dislocated (Figure 1). Chest X-ray showed no abnormal lesions. Tumor markers AFP, CA19-9 and CEA were all negative. Fecal occult blood test was also negative. Both glutamate alanine aminotransferase and glutamic oxaloacetic transaminase were in the normal range.

\author{
Corresponding author: \\ Qi-Lian Liang MD \\ Department of Oncology \\ Affiliated Hospital \\ of Guangdong \\ Medical College \\ 57 People Avenue \\ Zhanjiang 524001 \\ Guangdong, China \\ Phone: 86-759-2387455 \\ Fax: 86-759-2231754 \\ E-mail: \\ lianqilian@gdmc.edu.cn
}




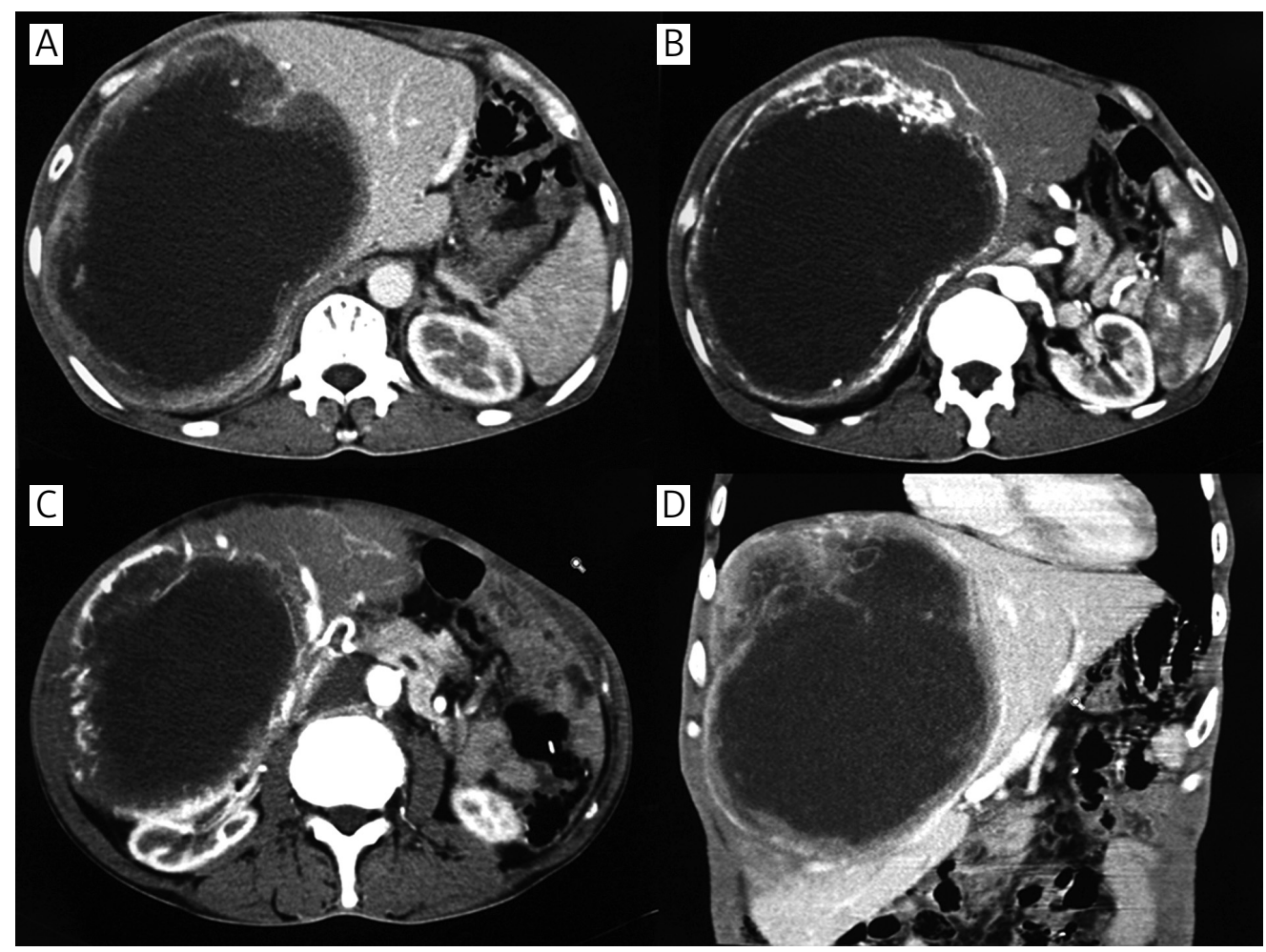

Figure 1. Contrast-enhanced computerized tomography. Contrast-enhanced CT shows a large mass about $17 \mathrm{~cm} \times 20 \mathrm{~cm}$ almost occupying the full right lobe of the liver, which was encircled by rich blood vessels. The pancreas and right kidney were dislocated (A, B, C - transverse scan; D - coronal scan)

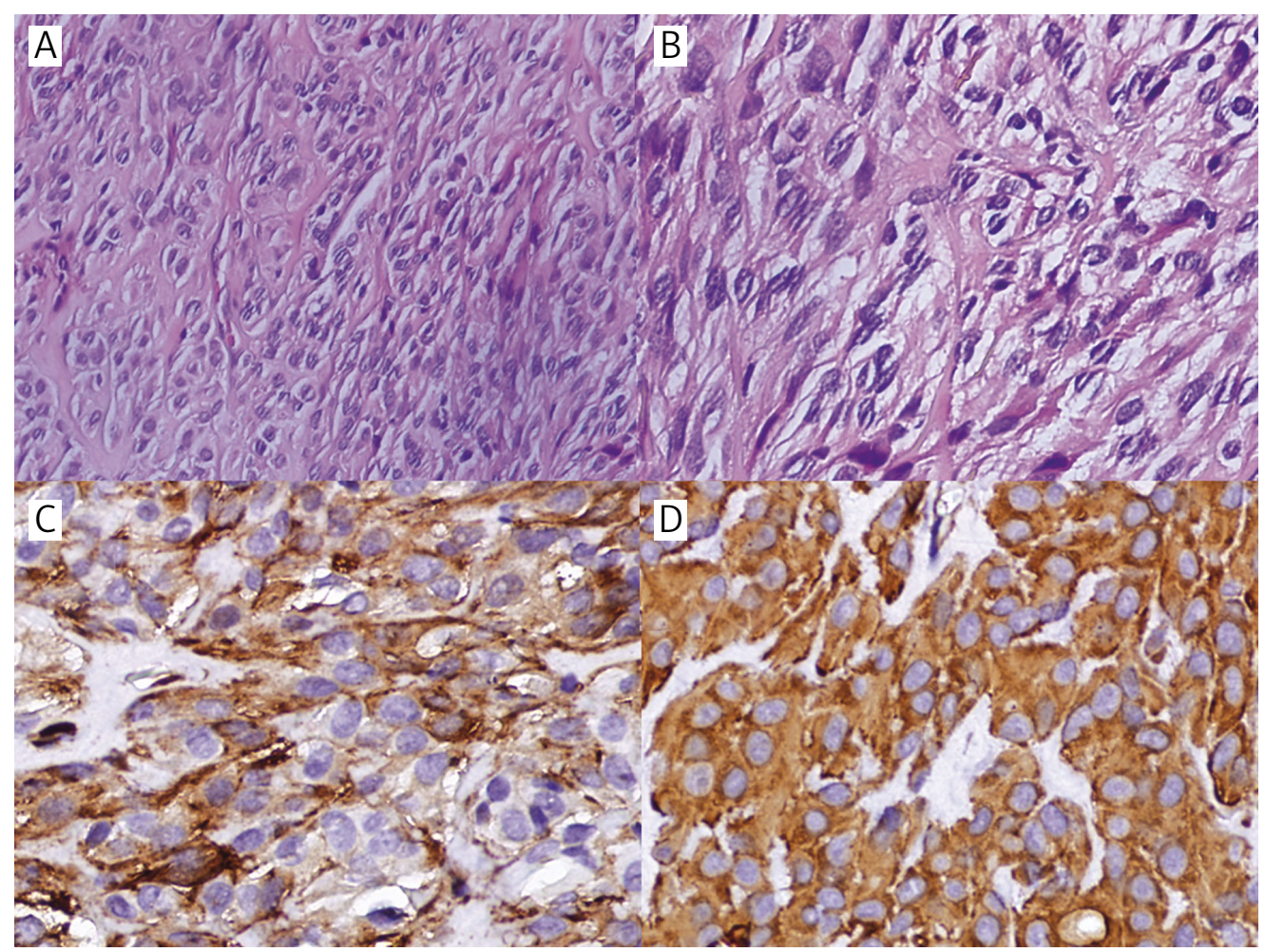

Figure 2. Histological and immunohistochemical findings of hepatic EGIST. A - The tumor is composed of spindle cells (hematoxylin and original magnification 200x). B - The spindle cells show pleomorphic nuclei, commonly vacuoles beside the nuclei and abundant intercellular collagen (hematoxylin and original magnification 400x). C - The tumor cells test positive for SMA (original magnification 400x). D - Vimentin is diffusely and strongly positive in the tumor cells (original magnification 400x) 


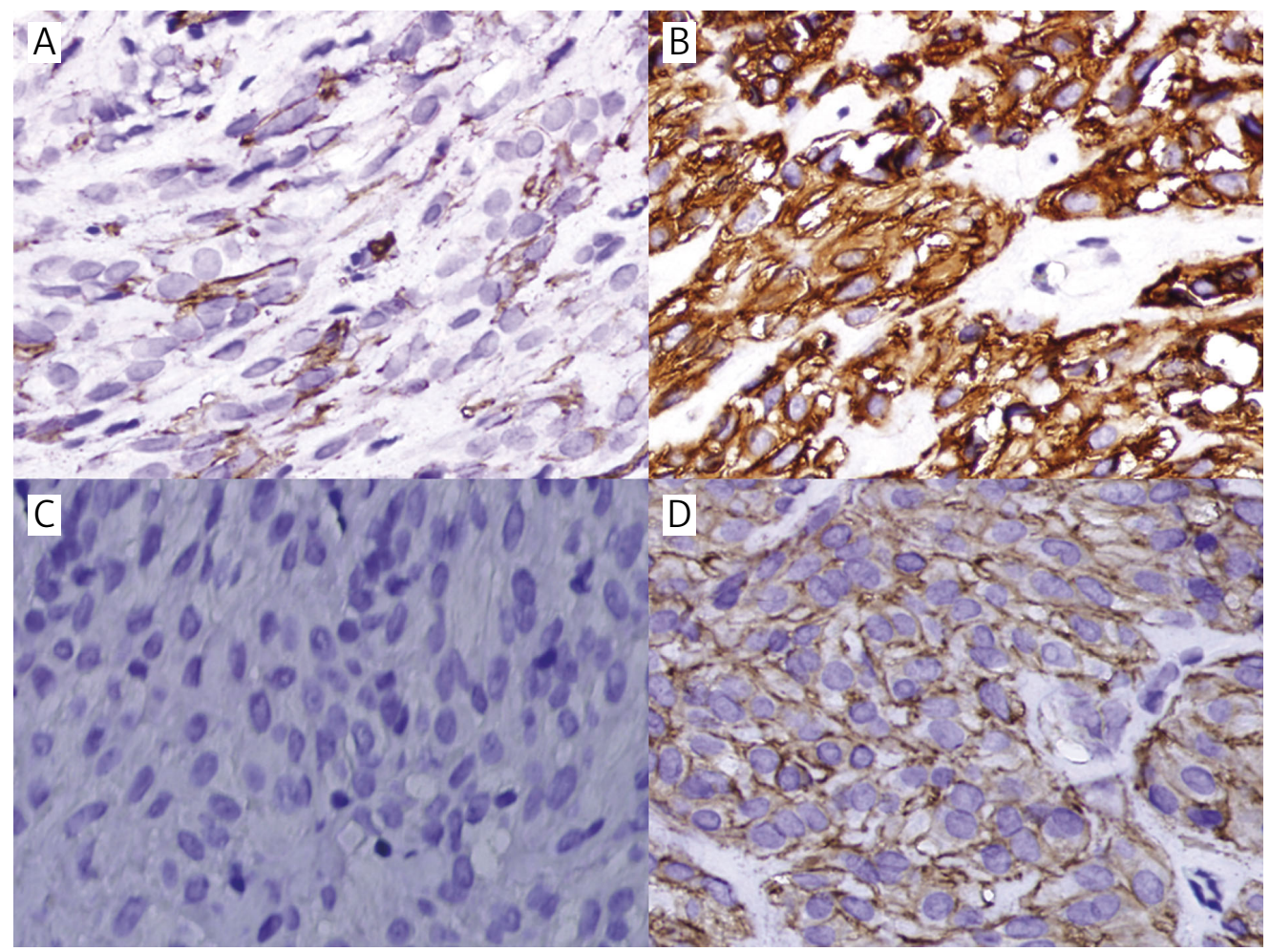

Figure 3. Immunohistochemical findings of hepatic EGIST. A - CD34 positive in tumor cells (original magnification 400x). B - CD117 positive in tumor cells (original magnification 400x). C - CK negative in tumor cells (original magnification 400x). D - DOG-1 focally positive in tumor cells (original magnification 400x)

$\mathrm{HBsAg}, \mathrm{HBeAb}$ and $\mathrm{HBcAb}$ were positive in second liver two half-and-half tests.

Due to the patient's condition, hepatectomy could not be performed, and a US-FNAB from the liver mass was taken. Histologically the tumor consisted of spindle cells with pleomorphic nuclei, commonly vacuoles beside the nuclei and abundant intercellular collagen (Figures 2 A-B). Immunohistochemical analysis revealed that the spindle cells were positive for CD117 (Figure 3 B), CD34 (Fi- gure $3 \mathrm{~A}$ ), discovered on GIST1 (DOG-1) (focal) (Figure $3 \mathrm{D}$ ), SMA (Figure $2 \mathrm{C}$ ), and vimentin ( $\mathrm{Fi}$ gure $2 \mathrm{D}$ ), while they were negative for CK (Figure $3 \mathrm{C}$ ) and S-100 (figure not shown). All these results indicated that the diagnosis was extra-gastrointestinal stromal tumor. The tumor's mitotic activity could not be evaluated because of the small amount of examined material. KIT gene mutation analysis was not performed due to its non-availability at our institute.

Table I. Hepatic EGIST reported in the literature

\begin{tabular}{|lcccccccc|}
\hline Author, year & $\begin{array}{c}\text { Age } \\
\text { [years] }\end{array}$ & Gender & $\begin{array}{c}\text { Tumor } \\
\text { size }[\mathrm{cm}]\end{array}$ & Cell type & $\begin{array}{c}\text { Mitosis/ } \\
\text { 50HPFa }\end{array}$ & CD117 & CD34 & Outcome \\
\hline $\begin{array}{l}\text { Yamamoto } \\
\text { et al., } 2010\end{array}$ & 70 & Male & 20 & Epithelioid & 1 & - & + & NA $^{\text {b }}$ \\
\hline $\begin{array}{l}\text { Luo et al., } \\
2009\end{array}$ & 17 & Male & 5.1 & Spindle & NA & + & + & $\begin{array}{c}\text { Alive and } \\
\text { well } 3 \text { months }\end{array}$ \\
\hline $\begin{array}{l}\text { Ochiai et al., } \\
2009\end{array}$ & 30 & Male & $>10$ & Mixed & 75 & + & + & $\begin{array}{c}\text { Alive and } \\
\text { well } 42 \text { months }\end{array}$ \\
\hline $\begin{array}{l}\text { De Chiara et al., } \\
2006\end{array}$ & 37 & Male & 18 & Spindle & 20 & + & - & $\begin{array}{c}\text { Alive and } \\
\text { well } 36 \text { months }\end{array}$ \\
\hline $\begin{array}{l}\text { Hu et al., 2003 } \\
\text { The current study }\end{array}$ & 53 & Female & 15 & Spindle & $4 / 10 \mathrm{HPF}$ & + & + & $\begin{array}{l}\text { Recurrence } \\
16 \text { months }\end{array}$ \\
\hline The & Male & 20 & Spindle & NA & + & + & NA \\
\hline
\end{tabular}

aHPF - high-power field, bNA - not available 
We advised the patient to take imatinib mesylate (Glivec), but he refused because of financial problems, and was discharged 13 days later.

Gastrointestinal stromal tumor (GIST) is a common tumor of the gastrointestinal tract, which mainly occurs in the stomach. When this kind of neoplasm develops outside the gastrointestinal tract, it is defined as EGIST. Metastasis of GIST to the liver is very common, while primary GIST of the liver is extremely rare. To the best of our knowledge, only 5 cases of primary hepatic EGIST have been reported previously in English [13-17] (Table I). There is a distinct male predominance, and their age ranges from 17 to 79 years, average 47.7 years. The majority have a large tumor size, only one under $10 \mathrm{~cm}$. Four of 6 cases have a spindle cell type. Both CD117 and CD34 have only one case that is negative. The mitotic rate and outcome are hard to analyze. Due to the particularity of hepatic EGIST, it should be diagnosed differentially with primary or metastatic poorly differentiated carcinoma, angiomyolipoma, leiomyosarcoma, or malignant melanoma. $\mathrm{HMB}-45$ and $\mathrm{PKC} \theta$ were recommended in immunohistochemical analysis, so as to exclude the mimics mentioned above [17].

US-FNAC is the quickest and least painful way to obtain an accurate tissue diagnosis of a lump anywhere in the body. There are three steps in US-FNAC: firstly, the position, size and adjacent structure of the lesion are evaluated by ultrasound; secondly, two or more samples are taken with a 23gauge or 25-gauge needle; lastly, the obtained samples are stained and examined by a pathologist. It has multiple advantages compared to open biopsy, which is not only inexpensive and minimally invasive but is also performed simply and easily. Furthermore, it allows surgery or neoadjuvant treatment to be performed expeditiously with a confirmed preoperative diagnosis. An accurate diagnosis is made with the combination of clinical examination, radiology and FNAC. Although EGIST is rare, it also could be diagnosed by this technique. Rao et al. [26] reported a case and reviewed three cases of pancreatic EGIST, which were diagnosed by US-FNAC. Luo et al. [15] showed that there was no exception on hepatic EGIST. The present case revealed that the biopsy samples were enough for cytological analysis, although the mitotic rate could not be determined.

In order to understand EGIST more clearly, we have reviewed several quite large studies [1-4, 27-30] (Table II) published recently. When these data are summarized together, some similarities can be seen distinctly. The incidence of EGIST is $5 \%-7 \%$ of cases of GIST [4, 28], with a female predominance (64.9\%, 98/151), and the most frequent lesion sites are the mesentery, omentum and retroperitoneum [1-4]. The median age is 58.5 years, which is simi-

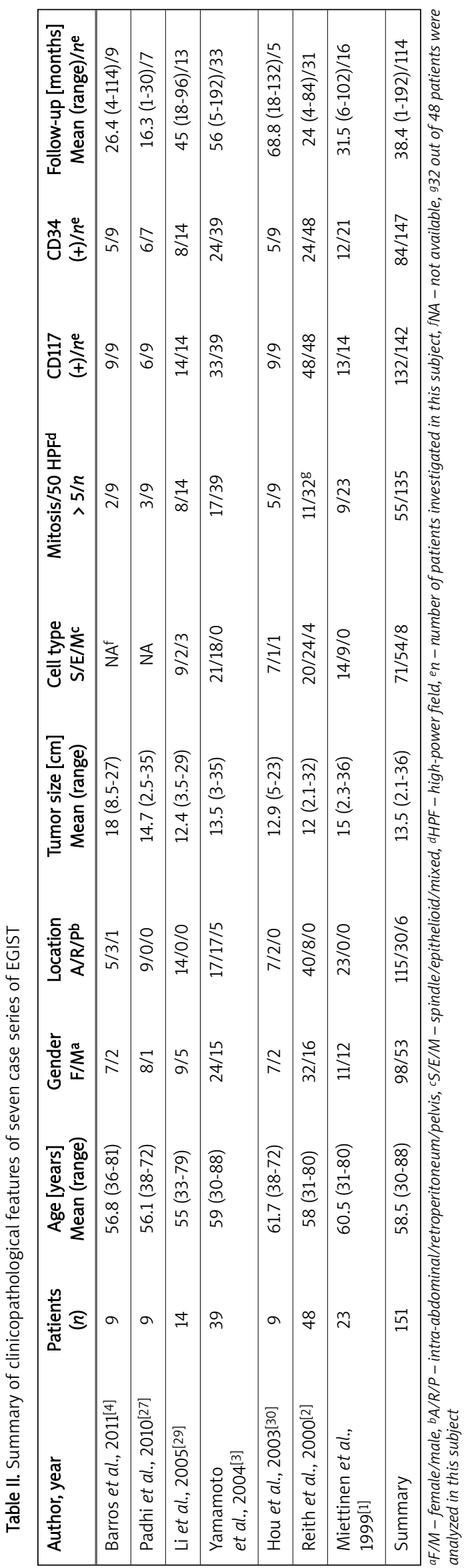


lar to jejunal and ileal GISTs (59 years) [31]. Due to EGIST being outside of the gastrointestinal tract, there are no common symptoms such as bleeding or obstruction. Furthermore, the abdominopelvic cavity and retroperitoneum have enough room for a neoplasm to grow. Thus most of the cases presented a tremendous mass when first detected, with median size of $13.5 \mathrm{~cm}$. Whether the tumor size is a prognostic factor or not, it should be taken into account. Reith et al. [2] found that there were no significant differences between large $(>10 \mathrm{~cm})$ and small $(\leq 10 \mathrm{~cm})$ tumors in outcome. The cell morphological pattern of EGIST is predominantly spindle (71 cases) or epithelioid (54 cases). Three studies [1-3], in which the number of patients was more than 20, were in accord with the figure. Spindle cell EGIST should be diagnosed differentially with smooth muscle tumors, schwannoma, solitary fibrous tumor and sarcomatoid carcinoma, while epithelioid EGIST should be diagnosed differentially with metastatic melanoma, carcinoma, clear cell sarcoma and epithelioid hemangioendothelioma [32]. More than one third (55/135) of cases displayed a mitotic index more than 5 per high-power field (HPF). Yamamoto et al. [3] revealed that a high mitotic rate ( $\geq 5 / 50$ HPF) had significantly shorter disease-specific survival than a low rate $(<5 / 50 \mathrm{HPF})(p=0.015)$. Almost $100 \%$ were positive for CD117 [2-4, 29]. We think that it may be because most of them are retrospective studies. The patients were used to being easily misdiag nosed with other diseases. With this type of issue, CD117 was recommended as a selection criterion. CD117-negative tumors should be taken seriously; it still cannot exclude EGIST. Demetri et al. [32] recommended using DOG-1 as a candidate when CD117 immunostaining and mutation testing for KIT and PDGFRA were all negative. About 57.1\% (84/147) of patients were CD34-positive, which was lower than GIST (81\%) [33]. Other antibody markers were different in these studies; thus it was hard to analyze. Considering the follow-up data from different studies, it is very difficult to reach a persuasive conclusion. However, there is a trend that EGIST is an aggressive group with worse outcome.

In conclusion, we have presented a case of hepatic EGIST diagnosed by US-FNAC. The incidence of EGIST is low, and it has a younger age of diagnosis and large tumor size. The mitotic index can be a prognostic factor; however, tumor size still needs more proof. Furthermore, EGIST can be misdiagnosed for other diseases, and clinicians should take it seriously.

\section{References}

1. Miettinen M, Monihan JM, Sarlomo-Rikala M, et al. Gastrointestinal stromal tumors/smooth muscle tumors (GISTs) primary in the omentum and mesentery: clinicopathologic and immunohistochemical study of 26 cases. Am J Surg Pathol 1999; 23: 1109-18.

2. Reith JD, Goldblum JR, Lyles RH, Weiss SW. Extragastrointestinal (soft tissue) stromal tumors: an analysis of 48 cases with emphasis on histologic predictors of outcome. Mod Pathol 2000; 13: 577-85.

3. Yamamoto H, Oda Y, Kawaguchi K, et al. c-kit and PDGFRA mutations in extragastrointestinal stromal tumor (gastrointestinal stromal tumor of the soft tissue). Am J Surg Pathol 2004; 28: 479-88.

4. Barros A, Linhares $E$, Valadao $M$, et al. Extragastrointestinal stromal tumors (EGIST): a series of case reports. Hepatogastroenterology 2011; 58: 865-8.

5. Long KB, Butrynski JE, Blank SD, et al. Primary extragastrointestinal stromal tumor of the pleura: report of a unique case with genetic confirmation. Am J Surg Pathol 2010; 34: 907-12.

6. Cecka F, Jon B, Ferko A, Subrt Z, Nikolov DH, Tycova V. Long-term survival of a patient after resection of a gastrointestinal stromal tumor arising from the pancreas. Hepatobiliary Pancreat Dis Int 2011; 10: 330-2.

7. Rao RN, Vij M, Singla N, Kumar A. Malignant pancreatic extra-gastrointestinal stromal tumor diagnosed by ultrasound guided fine needle aspiration cytology. A case report with a review of the literature. JOP 2011; 12: 283-6.

8. Vij M, Agrawal V, Pandey R. Malignant extra-gastrointestinal stromal tumor of the pancreas. A case report and review of literature. JOP 2011; 12: 200-4.

9. Yang F, Jin C, Fu D, Ni Q. Extra-gastrointestinal stromal tumor of the pancreas: clinical characteristics, diagnosis, treatment, and outcome. J Surg Oncol 2011; 103: 739-40.

10. Hirabayashi K, Fujihira T, Oyamada H, et al. First case of primary phyllodes tumor of the pancreas: case report and findings of immunohistochemical and ultrastructural studies. Virchows Arch 2010; 456: 587-93.

11. Showalter SL, Lloyd JM, Glassman DT, Berger AC. Extragastrointestinal stromal tumor of the pancreas: case report and a review of the literature. Arch Surg 2008; 143: 305-8.

12. Yamaura K, Kato K, Miyazawa M, et al. Stromal tumor of the pancreas with expression of c-kit protein: report of a case. J Gastroenterol Hepatol 2004; 19: 467-70.

13. De Chiara A, De Rosa V, Lastoria S, et al. Primary gastrointestinal stromal tumor of the liver with lung metastases successfully treated with STI-571 (imatinib mesylate). Front Biosci 2006; 11: 498-501.

14. Hu X, Forster J, Damjanov I. Primary malignant gastrointestinal stromal tumor of the liver. Arch Pathol Lab Med 2003; 127: 1606-8.

15. Luo XL, Liu D, Yang J), et al. Primary gastrointestinal stromal tumor of the liver: a case report. World J Gastroenterol 2009; 15: 3704-7.

16. Ochiai T, Sonoyama T, Kikuchi S, et al. Primary large gastrointestinal stromal tumor of the liver: report of a case. Surg Today 2009; 39: 633-6.

17. Yamamoto $H$, Miyamoto $Y$, Nishihara $Y$, et al. Primary gastrointestinal stromal tumor of the liver with PDGFRA gene mutation. Hum Pathol 2010; 41: 605-9.

18. Park JK, Choi SH, Lee S, Min KO, Yun SS, Jeon HM. Malignant gastrointestinal stromal tumor of the gallbladder. J Korean Med Sci 2004; 19: 763-7.

19. Sereg M, Buzogány I, Gonda G, et al. Gastrointestinal stromal tumor presenting as a hormonally inactive adrenal mass. Endocrine 2011; 39: 1-5.

20. Shin HS, Cho CH, Kum YS. Extragastrointestinal stromal tumor of the urinary bladder: a case report. Urol J 2011; 8: 165-7. 
21. Mekni A, Chelly I, Azzouz H, et al. Extragastrointestinal stromal tumor of the urinary wall bladder: case report and review of the literature. Pathologica 2008; 100: 173-5.

22. Krokowski M, Jocham D, Choi H, Feller AC, Horny HP. Malignant extragastrointestinal stromal tumor of bladder. J Urol 2003; 169: 1790-1.

23. Yinghao S, Bo Y, Xiaofeng G. Extragastrointestinal stromal tumor possibly originating from the prostate. Int J Urol 2007; 14: 869-71.

24. Kim YJ, Jeong YY, Kim SM. Extragastrointestinal stromal tumor arising from the vagina: MR findings. Eur Radiol 2006; 16: 1860-1.

25. Weppler EH, Gaertner EM. Malignant extragastrointestinal stromal tumor presenting as a vaginal mass: report of an unusual case with literature review. Int I Gynecol Cancer 2005; 15: 1169-72.

26. Rao RN, Vij M, Singla N, Kumar A. Malignant pancreatic extra-gastrointestinal stromal tumor diagnosed by ultrasound guided fine needle aspiration cytology: a case report with a review of the literature. J Pancreas 2011; 12: 283-6.

27. Padhi S, Kongara R, Uppin SG, et al. Extragastrointestinal stromal tumor arising in the pancreas: a case report with a review of the literature. JOP 2010; 11: 244-8.

28. Zhang W, Peng Z, Xu L. Extragastrointestinal stromal tumor arising in the rectovaginal septum: report of an unusual case with literature review. Gynecol Oncol 2009; 113: 399-401.

29. Li ZY, Huan XQ, Liang XJ, Li ZS, Tan AZ. Clinicopathological and immunohistochemical study of extra-gastrointestinal stromal tumors arising from the omentum and mesentery [Chinese]. Zhonghua Bing Li Xue Za Zhi 2005; 34: 11-4.

30. Hou YY, Sun MH, Wei YK, et al. Clinicopathological, immunohistochemical and molecular genetic study of intra-abdomen extra-gastrointestinal stromal tumors [Chinese]. Zhonghua Bing Li Xue Za Zhi 2003; 32: 422-6.

31. Miettinen M, Makhlouf H, Sobin LH, Lasota J. Gastrointestinal stromal tumors of the jejunum and ileum: a clinicopathologic, immunohistochemical, and molecular genetic study of 906 cases before imatinib with long-term follow-up. Am J Surg Pathol 2006; 30: 477-89.

32. Demetri GD, von Mehren M, Antonescu CR, et al. NCCN Task Force report. Update on the management of patients with gastrointestinal stromal tumors. J Natl Compr Canc Netw 2010; 8 Suppl 2: S1-41.

33. Miettinen M, Sobin LH, Lasota J. Gastrointestinal stromal tumors of the stomach: a clinicopathologic, immunohistochemical, and molecular genetic study of 1765 cases with long-term follow-up. Am J Surg Pathol 2005; 29: 52-68. 